\title{
Myocardial tissue characterization by magnetic resonance imaging
}

\section{Helena Antić \\ Kauzlarić ${ }^{*}$}

Clinic for Treatment, Rehabilitation and Prevention of Cardiovascular Diseases, Thalassoterapia Opatija, Opatija, Croatia
KEYWORDS: cardiac magnetic resonance imaging, T1-mapping, T2-mapping.

CITATION: Cardiol Croat. 2017;12(4):134. | https://doi.org/10.15836/ccar2017.134

*ADDRESS FOR CORRESPONDENCE: Helena Antić Kauzlarić, Thalassotherapia Opatija - Klinika za liječenje, rehabilitaciju i prevenciju bolesti srca i krvnih žila, Ul. Maršala Tita 188, HR-51410 Opatija, Croatia. Phone: +385-51-202-720 / E-mail: helantic@gmail.com

ORCID: Helena Antić Kauzlarić, http://orcid.org/0000-0002-2563-7441

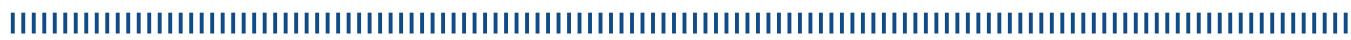

Cardiac magnetic resonance (CMR) imaging is a well-established noninvasive imaging modality in clinical cardiology. Its unsurpassed accuracy in defining cardiac morphology and function and its ability to provide tissue characterization make it well suited for the study of patients with cardiac diseases. With or without administration of an exogenous contrast agent, cardiac MRI affords detailed myocardial tissue characterization via various segmented as well as single heart beat approaches Late gadolinium enhancement was a major advancement in the development of tissue characterization techniques, allowing the unique ability of CMR to differentiate ischemic heart disease from nonischemic cardiomyopathies. Using T2-weighted techniques, areas of edema and inflammation can be identified in the myocardium. To characterize other myocardial features, imaging techniques that capture intrinsic contrast in T1, T2 and other MR-based relaxation parameters are often incorporated into the cardiac MRI examination. Accruing evidence suggests that quantitative approaches, also known as tissue mapping techniques, are helping to further advance MR-based myocardial characterization. A new generation of myocardial mapping techniques are emerging, enabling direct quantitative assessment of myocardial tissue properties in absolute term..$^{1-3}$ This review will summarize recent developments involving T1-mapping and T2-mapping techniques and focus on the clinical applications and future potential of these evolving CMR methodologies.
\end{abstract}

RECEIVED:

March 11, 2017

ACCEPTED:

April 6, 2017

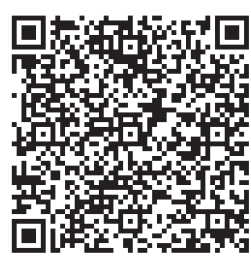

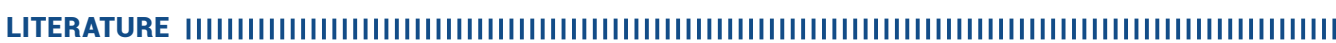

1. Sharma V, Binukrishnan S, Schoepf UJ, Ruzsics B, Myocardial tissue characterization with magnetic resonance imaging. J Thorac Imaging. 2014 Nov;29(6):318-30. https://doi.org/10.1097/RTI.0000000000000053

2. University of Minnesota. Cardiac Magnetic Resonance Imaging Tutorial: Tissue Characterization. http://www.vhlab.umn.edu/atlas/cardiac-mri-tutorial/tissue-characterization.shtml (10.3. 2017).

3. Carlsson M, Xanthis CG, Smart S, Bidhult S, Aletras AH. Tissue Characterization: T1, T2 and T2* Techniques. In: Syed MA, Raman SV, Simoneeti OP (Eds). Basic Principles of Cardiovascular MRI. Springer International Publishing. 2015, pp 167-177. https://doi.org/10.1007/978-3-319-22141-0_12 